\title{
DIRECTIONALIY SOLIDIFIED EUTECTICS AS HIGH TEMPERATURE FASTENERS
}

\author{
I'. D. George \\ United Aircraft Research Laboratories \\ Fast Hartford, Connecticut
}

\section{Abstract}

In a number of laboratories, directionally solidified eutectics are being examined as candidate materials for varles and blades ir ddvanced gas turvines. Because of the superior high temperature properties displayed by two such alloys, a program was initiated to determine the suitability of these materials for hich temperature f'asteners.

Material properties pertinent to fastener applications were determined as a function of temperature. These properties included shear parallel and perpendicular to the growth direction and torsion parallel to the growth direction. Several techniques were investigated for fabricating typical fastener shapes. These fabrication methods included grinding, creep forming and direct casting. Finally, a brief evaluation of the performance of the best fabricated fastener design was made.

This study was funded by the National Aeronautics and Space Administration at Marshall Space Flight Center under contract No. NAS8-27.358.

\section{Introduction}

In recognition of the current and anticipated requirements for superior high temperature materials, the Materials Laboratory of UARL has directed a substantial rescarch cffort in the establishmont and cvaluation of a tcchnology for growing phase-reinforced eutectic alloys. The techniques used have demonstrated that materials with superior mechanical properties can be processed by the directional solidification of high temperature eutectic alloys. These investigations were prompted for the main purpose of developing an alloy for use in high temperature turbine applications. Several nickel and cobalt-based, phase-reinforced composite systems have been identified which display superior mechanical properties for temperatures to $2200^{\circ} \mathrm{F}$. Certain of the characteristics, notably microstructural stability, tension, creep and fatigue, suggested that these type materials might qualify as high temperature fasteners for attaching thermal protection panels on space vehicles. For cxample, good microstructural stability would assure non-weakening of the fastener head area at the working temperatures and high creep resistance would prevent relaxation under load and help retain a "tight joint".

In comparison with other techniques for obtaining superior high temperature materials, the directionally solidified eutectic approach offers numerous advantages. one of the most important advantages is that a eutectic composite develops its reinforcing phase in situ by a one-step casting process. Since the composite structures are generated as a result of an equilibrium rcaction, the phases produccd are chemically stable with respect to one another. Furthermore, experience has shown that the low energy interfaces, established during the growth, result in a microstructure with exceptional stability which resists coarsening and spheroidization. Mechanically, as a first approximation, the behavior of these materials can be treated as normal composites. Recently it has been shown, however, that there is an important 
effect of interphase spacing on strength. Reducing this spacing, which is accomplished by growing the material at a faster rate, has strengthened the material according to a Hall-Petch relationship. Thus, not only is processing benefited by rate increases but also properties.

Included in the disadvantages in the eutectic approach are anisotropic properties (as with other composites), a general inability to vary randomly the volume fraction of the phases, and some lack of frcedom in sclection of interesting systems. These last two disadvantages occur because we have selected to use a eutectic or eutecticlike composition where two or more phases crystallize simultaneously from a liquid. Even within these limitations, there are countless systems which can be anticipated if one considers ternary and higher order systems for study and development.

The prime material evaluated in this study was the directionally solidified $\mathrm{Ni}_{3} \mathrm{~A} \perp-\mathrm{Hi} 3 \mathrm{Cb}$ eutectic a L Ly $(1-b)$. Atter soliditication the microstructure consists of a lamellar (sheet-like) dispersion of $\mathrm{Ni}_{3} \mathrm{Cb}$ within a $\mathrm{Ni}_{3} \mathrm{Al} \operatorname{matrix}$ (Fig. I). It contains approximately 44 volume percent of the $\mathrm{Ni} 3 \mathrm{Cb}$ reinforcing phase and the $\mathrm{Ni} 3 \mathrm{Al}$ matrix (a ductile intermetallic compound) is strengthened substantially by the 8 at. \% columbium dissolved within it. The eutectic melting temperature is $2335^{\circ} \mathrm{F}$ and its density is $8.5 \mathrm{gm} / \mathrm{cc}$. The alloy is a high modulus material whose tensile strength and creep-rupture strength are markedly superior to conventional superalloys. It is mildly notch sensitive at room temperature but is notch insensitive at elevated temperatures. Although it possesses low tensile ductility at room temperature, this does not mean the material is brittle. Its toughness is, in fact, comparable to superalloys at room temperature. The fatigue strength of the alloy is outstanding at room temperature, greatly surpassing that of nickel superalloys. This eutectic alloy exhibits such remarkable properties by virtue of the directional nature of its microstructure. The properties of the material are, as a consequence, directional. This material offers interesting possibilities for application as a high temperature fastener and if successfully developed, should satisfy performance requirements which cannot be met by conventional materials.

Since the $\mathrm{Ni} 3 \mathrm{Al}-\mathrm{Ni}_{3} \mathrm{Cb}$ alloy is representative of only one class of eutectic composites, i.e. the lameliar reinforced, a limited evaluation of the $(\mathrm{Co}, \mathrm{Cr})-(\mathrm{Cr}, \mathrm{Co}) 7_{3} \mathrm{C}_{3}$ eutectic (6-9) which is representative of the fibrous reinforced eutectic composite was also included in this program. This cobalt-based eutectic was modified by the addition of aluminum for the purpose of improving its oxidation resistance and to aid in stabilizing the cubic form of the cobalt in the alloy. The microstructure of this alloy is fibrous in nature (Fig. 1) and consists of approximately 26 volume percent of the carbide reinforcing phase with a cobalt, chromium, aluminum solid solution matrix. It has a density of $8.0 \mathrm{gm} / \mathrm{cc}$ and a melting temperature of $2370^{\circ} \mathrm{F}$. Although not as strong as the $\mathrm{Ni}_{3} \mathrm{Al}_{\mathrm{Ai}} \mathrm{Nb}$ eutectic alloy, the (Co, $\left.\mathrm{Cr}, \mathrm{Al}\right)-(\mathrm{Cr}, \mathrm{Co}) \mathrm{F}_{3}$ eutectic is more easily grown - rates of $50 \mathrm{~cm} / \mathrm{hr}$ are typical - and is more oxidation resistant than the $\mathrm{Ni} 3^{\mathrm{Al}-\mathrm{Ni}} 3^{\mathrm{Cb}}$ eulectic. This alloy is stronger than the conventional cast nickelbase superalloys in tension and creep and has comparable impact toughness. Because of the presence of the aligned fibrous carbide phase, it displays a high elastic modulus at room and elevated temperatures.

Other examples of "exotic" alloys which have been selected for study as candidate materials for potential use as high temperature structural fasteners include a dispersion strengthened metal TD $\mathrm{NiCr}$ (10) and these evaluations will be used for comparison purposes where possible. 
Melting and Solidification Process

Master melts of eutectic composition were made in alumina crucibles and chillcast in copper molds. The resulting bars were then placed in $1 / 2$ inch diameter $99.7 \%$ recrystallized alumina cylindrical crucibles and unidirectionally solidified vertically within a resistuvely heated graphite tube furnace under a dynamic argon atmosphere (Fig. 2). These crucibles were held in a graphite sleeve which separated the crucible bottom from a water cooled brass pedestal by $1 / 4$ inch of graphite. The crucibles were lowered from the furnace at rates corresponding to a nominal* solidification velocity of $2 \mathrm{~cm} / \mathrm{hr}$ for the $\mathrm{Ni}_{3} \mathrm{Al}-\mathrm{Ni} 3 \mathrm{Cb}$ eutectic and $\mathrm{lo} \mathrm{cm} / \mathrm{hr}$ for the $(\mathrm{Co}, \mathrm{Cr}, \mathrm{Al})-(\mathrm{Cr}, \mathrm{Co})_{7} \mathrm{C}_{3}$ eutectic. Liquid superheats of approximately $500^{\circ} \mathrm{F}$ were employed and the themal gradient in the liquid was estimated to have been $160^{\circ} \mathrm{F} / \mathrm{cm}$. Several $1 / 2$ inch diameter ingots of both materials were formed as cast products by this vertical Bridgman-type directional solidification process. These ingots were then ground into test samples for the determination of the material properties pertinent to fastener application.

Material Property Fivaluation Pertinent to Fastener Apolication

Transverse Shear

Bar samples rectangular in cross-section, $1 / 8 \mathrm{inch} \times 1 / 4$ inch $\mathrm{x} I$ inch, were ground from the $1 / 2$ inch diameter ingots with the direction of solidification parallel to the longest dimension so the strength in shear perpendicular (transverse) to the growth direction might be moasured.

A double shear test fixture was used in this evaluation and initially the effect of span variations and the effect of the sample ends being clamped or free on the room temperature transverse shear strength were determined. High shear strength values were measured at short spans (0.010 inch) where the sample was supported in part by the anvïl and lower apparent shear strengths were measured at longer spans ( 0.073 inch) where failure appeared to have occurred partly by bending. Samples tested at the intermediate span distances appeared to have failed in shear and the mean value was considered as the effectivo shcar strongth of the material at room temperature. There was little effect due to clamping the sample ends at the intermediate spans where shear failures were observed. Because of this all high temperature tests were run with free ends at a constant span ( 0.030 inch) within the intermediate range. The transverse shear tests were performed at a loading rate of 0.01 in. $/ \mathrm{min}$.

In Fig. 3, a plot of effective shear stress vs. temperature indicates that the transverse shear strength of the $\mathrm{Ni}_{3} \mathrm{Al}-\mathrm{Ni}{ }_{3} \mathrm{Cb}$ euleclic is insensitive to temperature up to $1000^{\circ} \mathrm{F}$. The transversely oriented $\mathrm{Ni}_{3} \mathrm{Al}-\mathrm{Ni} 3_{\mathrm{Cb}}$ displayed increasing ductility with temperature. The specimens pictured indicate the brittle failure at room temperature and the ductile behavior at $2200^{\circ} \mathrm{F}$. The temperature dependence of transverse shear strength of the (Co, Cr, Al)- $\mathrm{Cr}, \mathrm{Co}{ }_{7} \mathrm{C}_{3}$ material is also shown in Fig. 3 . This eutectic shows only a slight decrease in shear strength up to $1000^{\circ} \mathrm{F}$ and at that temperature exhibits a shear strength equivalent to that observed for the $\mathrm{Ni} 3^{\mathrm{Al}-\mathrm{Ni}} \mathrm{Cb}^{\mathrm{Cb}}$ eutectic. Above this temperature, the shear strength drops oft rather rapidly. The test specimens in Fig. 3 also show the increase in ductility with temperature. Finally,

*The failure to develop an exactly uniform rate of growth is primarily the result of the changing thermal gradient in the solid. 
in Fig. 3, the shear strength values determined for $1 / 4$ inch diameter specimens of TD $\mathrm{NiCr}$ (10) based on double shear testing are also shown. This dispersion strengthened metal which had been selected for study as a candidate material for potential use as a high temperature fastener yielded values that closely compare with those obtained for the fibrous ( $\mathrm{Co}, \mathrm{Cr}, \mathrm{Al})-(\mathrm{Cr}, \mathrm{CO}){ }_{7} \mathrm{C}_{3}$ eutectic.

Tongitudina? Shear

Test specimens of both eutectic alloys for measuring longitudinal shear strength, shear parallel to the direction of solidification, were ground to shape and tested. These specimens consisted of a $1 / 4$ inch diameter bolt shank with two $1 / 8$ inch thick heads (one at each end of the shank) which were attached to a fixture composed of two high temperature slotted button-head adapters and split ring washers (to assure full bearing on the specimen heads). All longitudinal shear tests were run at a loading rate of $0.01 \mathrm{in.} / \mathrm{min}$ and a shearing span distance of 0.010 inch.

The longitudinal shear strength values were determined using the diameter of the bolt shank in calculating the shear area. This approximation was used in the NijAl$\mathrm{Ni}_{3} \mathrm{Cb}$ eutectic tests because the actual sheared area, as seen in Fig. 4, was not perfectly cylindrical which reflects the effect of the different orientations of the Lamellae in the various grains sheared. A large amount of plasticity at the two higher temperatures is evident from the photographs in Fig. 4 of the specimens tested at these temperatures. The temperature dependence of longitudinal shear strength of the $\mathrm{Ni}_{3} \mathrm{Al}_{-} \mathrm{Ni}_{3} \mathrm{Cb}$ alloy is also shown in $\mathrm{Fig}$. 4. An initial increase in longitudinal. shear strength with an increase in temperature is evident. This increase is undoubtedly partly due to the increase in the flow stress of the Ni3Al phase with temperature. This anomalous behavior has also been found in a $\mathrm{Ni}_{3}(\mathrm{Al}, \mathrm{Cb})$ single phase alloy, which is similar to the matrix phase of this eutectic, by Thornton, et al (II). The yield strength of this intermetallic compound increases with temperature up to approximately $1292^{\circ} \mathrm{F}$.

The temperature dependence of longitudinal shear strength of the (Co,Cr,Al)$(\mathrm{Cr}, \mathrm{Co}) 7 \mathrm{C}_{3}$ alloy is shown in Fig. 5. The photographs of fractured specimens at the various temperatures clearly indicate a transition from a tensile mode of failure to a shear mode of failure with increasing temperature. Although the failure mode of most of these specimens did not appear to be purely shear, the effective shear strength values were determined by using the bolt shank diameter in calculating the shear area.

Longitudinal Thread Shear

Longitudinal thread shear specimens 2 inches long with 1/4-20 threads at either. end were ground from both eutectic ingots with the direction of solidification parallel to the long dimension. All longitudinal thread shear tests were run at a loading rate of $0.01 \mathrm{in.} / \mathrm{min}$. Because of the difficulty in determining the shear area in these test samples, several shadowgraphs were taken from different sides of the shear fracture surface and different areas were obtained. The shear strength values varied depending on the area used in the calculation and therefore an average value was used. In some more difficult cases, the values were calculated from shear areas determined from actual measurements (the width and length of thread sheared and the remaining sheared diameter).

The temperature dependence of longitudinal thread shear strength of the $\mathrm{Ni}_{3} \mathrm{Al}-$ $\mathrm{Ni}_{3} \mathrm{Cb}$ eutectic is shown in Fig. 6. Although the thread shear strength values obtained are higher than the values reported for the longitudinal shear strengths, the behavior 
of both appears similar with respect to the materials response to temperature. The higher apparent thread shear strength values may be due to the difficulty in accurately determining the sheared area.

Although an increase in longitudinal shear strength with an increase in temperature was previously evident (Fig. 4), it is more dramatic in the longitudinal thread shear strength (Fig. 6). As previously mentioned, this is partly due to the increase in the flow stress of the NizAl phase with temperature. This longitudinal shear strength increase in the thread tests may also be due in part to the increasing shear ductility which would allow more uniform engagement of the specimen threads and test adapter.

The temperature dependence of longitudinal thread shear strength of the (Co,Cr, Al)$(\mathrm{Cr}, \mathrm{Co}) 7 \mathrm{C}_{3}$ eutectic is also shown in $\mathrm{Fig}$. 6 . The thread shear strength values obtained are higher than the values reported for the longitudinal shear strengths, but again the behavior of both appears similar with respect to the materials response to temperature. The higher apparent thread shear strength values may again be due to the difficulty in accurately determining the sheared area.

Torsion

Solid rods of the $\mathbb{N i}_{3} \mathrm{Al}-\mathbb{N i}{ }_{3} \mathrm{Cb}$ eutectic with gage sections of 0.125 inch diameter and either 2 inches or 1 inch long, with the long axis parallel to the growth direction, worc fracturcd in torsion. Those results arc listed in Tablc 1.

Table 1

Torsional Strength of $\mathrm{Ni}_{3} \mathrm{Al}-\mathrm{Ni}_{3} \mathrm{Cb}$ Eutectic Solidified at $2 \mathrm{~cm} / \mathrm{hr}$

\begin{tabular}{|c|c|c|c|c|c|c|c|c|}
\hline $\begin{array}{l}\text { Specimen } \\
\text { Numper }\end{array}$ & $\begin{array}{c}\text { Temp. } \\
\mathrm{OF}_{\mathrm{F}}\end{array}$ & $\begin{array}{l}{ }^{\theta} \mathrm{PL} \\
\text { aeg. }\end{array}$ & $\begin{array}{c}103^{\tau} \mathrm{PL} \\
\end{array}$ & $\begin{array}{r}\gamma_{\%} \\
\end{array}$ & $10^{6^{G}} \mathrm{psi}$ & $\begin{array}{l}\theta_{f} \\
\text { deg. }\end{array}$ & $10^{3^{\mathrm{f}}} \mathrm{psi}$ & $\begin{array}{c}\gamma_{f} \\
\% \\
\end{array}$ \\
\hline$\left.*_{A 70} 43\right)_{1}-01$ & 75 & - & 22 & 0.21 & 10.6 & - & 61 & - \\
\hline$A 71-749$ & 75 & 6.9 & 42 & 0.76 & - & 113 & 72 & 12.3 \\
\hline$*_{A 70}-434-02$ & 400 & - & 27 & 0.29 & 9.2 & $\sim 270$ & 72 & $\sim 15.2$ \\
\hline A71-750 & 400 & 5.5 & 39 & 0.61 & - & 159 & 74 & 17.4 \\
\hline A7I- 751 & 1000 & 6.9 & 47 & 0.76 & - & 299 & 84 & 32.7 \\
\hline A72-339 & 1600 & 5.9 & 25 & 0.64 & - & 529 & 48 & 57.8 \\
\hline$A 72-338$ & 2200 & 1.7 & 4 & 0.19 & - & 889 & 16 & 97.0 \\
\hline
\end{tabular}

strain measured by a time scale which was converted to an angle of twist measurement sage length - 1 inch

rate of applied torque $=.67 \mathrm{RPM}$

G $\quad \equiv$ shear modulus

$\tau_{P I}, \tau_{f} \equiv$ shear stresses at proportional limit and at failure

$\gamma_{P L}, \gamma_{f} \equiv$ shear strains at proportional limit and at failure

$\theta_{\mathrm{PL}}, \theta_{\mathrm{f}} \equiv \mathrm{angle}$ of twist at proportional limit and at failure

$\equiv$ strain measured by bonded strain gages oriented in the direction of the principal stress (gage length $=2$ inches) 
The following equations were used in determining the values shown in Table 1 for the two strain gaged specimens.

$$
\begin{array}{ll}
\text { Shear stress at proportional limit* } & { }_{\mathrm{PL}}=\mathrm{Tr} / \mathrm{J} \\
\text { Shear strain at proportional limit* } & \gamma_{\mathrm{FL}}=2 \varepsilon\left(2 / \mathrm{G} . \mathrm{F}_{.}\right) \\
\text {Shear modulus** } & \mathrm{G}=\operatorname{Tr} / \mathrm{J} \gamma \\
\text { Shear stress at failure } & \tau_{f}=3 \mathrm{M}_{\mathrm{f}} / 2 \pi \mathrm{r}^{3}
\end{array}
$$

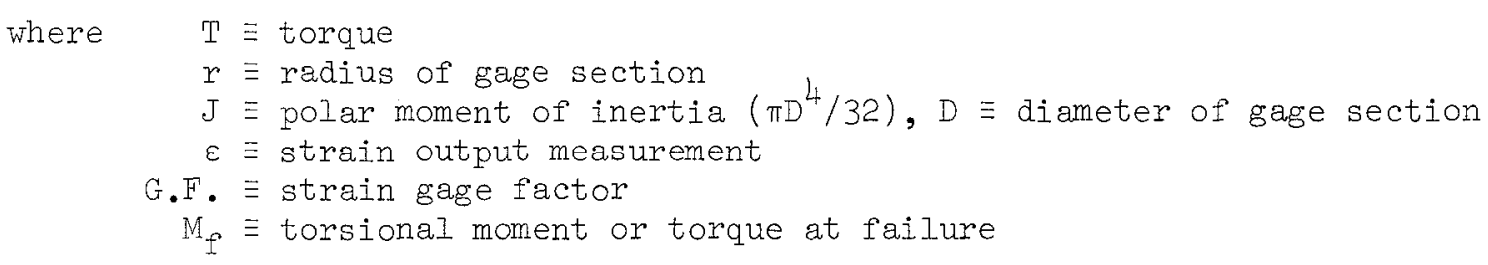

Shear stress values given for specimens where strain was measured by a time scale which was then converted to an angle of twist measurement $(\theta)$ were determined using Eqs. (1) and (4) for the shear stress at the proportional limit and at failure respectively. The shear strain values for lhese specimens al the propurliond limil and at failure were calculated using the following equation:

$$
\gamma=r \theta / I
$$

$$
\text { where } \begin{aligned}
r & \equiv \text { radius of gage section } \\
\theta & \equiv \text { angle of twist } \\
& L \equiv \text { length of gage section }
\end{aligned}
$$

There is an appreciable difference in both lhe shear stress and shear strain values at the proportional limit for specimens tested under the same conditions depending on the method used for measuring strain. This difference, however, is substantialiy reduced when these values are compared at the point of failure. The approximate shear strain value given in Table 1 for specimen number A70-434-02 was determined using Eq. (5) and a visual measurement of the angle of twist after failure.

The torque vs angle of twist curves for the $\mathrm{Ni}_{3} \mathrm{Al}-\mathrm{Ni}{ }_{3} \mathrm{Cb}$ alloy are shown in Fig. 7. The three curves, room temperature, $400^{\circ} \mathrm{F}$ and $1000^{\circ} \mathrm{F}$, essentially vary only in the degree of twist at failure which increases with increasing temperature. For these temperatures, characteristic of cold working, the torque increased continuously with angle of twist up to a maximum where the specimen separated. Also, the specimen tested at $1000^{\circ} \mathrm{F}$ experienced cracking, as noted in Fig. 7 , well before final failure occurred. The initial cracking was recorded at an angle of twist of 67.1 degrees. Using Eqs. (4) and (5), the shear stress and shear strain at crack initiation were calculated to be $56 \times 10^{3}$ psi and $7.3 \%$ respectively. For temperatures characteristic

\footnotetext{
*Proportional limit is defined as the point where the shear-stress and shear-strain curve first deviates from linearity.

* Shear modulus is determined from the slope of the linear portion of the shear-stress, shear-strain curve.
} 
of hot working, (e.g. 1600 and $2200^{\circ} \mathrm{F}$ ) the torque reached a peak and then gradually fell until the specimen fractured. For the $1600^{\circ} \mathrm{F}$ test, this peak occurred at an angle of twist of 467 degrees, a maximum shear stress of $51 \times 10^{3}$ psi and a shear strain of $51 \%$. The peak for the $2200^{\circ} \mathrm{F}$ test occurred at an angle of twist of 559 degrees and a shear stress and shear strain of $18 \times 10^{3}$ psi and $61 \%$ respectively. The corresponding fractured specimens at room temperature (brittle fracture) and $2200^{\circ} \mathrm{F}$ (ductile failure) are also shown in Fig. 7.

Solid rods of the $(\mathrm{Co}, \mathrm{Cr}, \mathrm{Al})-(\mathrm{Cr}, \mathrm{Co}){ }_{7} \mathrm{C}_{3}$ eutectic with a gage section of 0.125 inch diameter and $l$ inch long, with the long axis parallel to the growth direction, were fractured in torsion. These results are given in Table 2.

Table 2

Torsional Strenglh of (Co,Cr, AI)- $(\mathrm{Cr}, \mathrm{CO}){ }_{7} \mathrm{C}_{3}$ Euleclic Soliaified at $10 \mathrm{~cm} / \mathrm{hr}$

\begin{tabular}{|c|c|c|c|c|c|c|c|c|}
\hline $\begin{array}{l}\text { Specimen } \\
\text { Number }\end{array}$ & $\begin{array}{c}\text { Ternp. } \\
\mathrm{O}_{\mathrm{F}}\end{array}$ & $\begin{array}{l}\theta_{\mathrm{PL}} \\
\text { deg. }\end{array}$ & $\begin{array}{c}{ }^{\mathrm{T}} \mathrm{PL} \\
103^{\mathrm{psi}} \\
\end{array}$ & $\begin{array}{l}\gamma_{\mathrm{PL}} \\
\% \\
\end{array}$ & $10^{6^{G}} \mathrm{psi}$ & $\begin{array}{l}{ }_{\mathrm{f}} \\
\mathrm{deg} .\end{array}$ & $103^{\tau} \mathrm{psi}$ & $\gamma_{\frac{\rho}{2}}$ \\
\hline$* A 71-771 D$ & 75 & - & 33 & 0.27 & 12.0 & - & 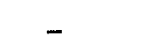 & \\
\hline A7I- $771 D$ & 75 & 6.9 & 56 & 0.76 & - & 126 & 89 & \\
\hline$*_{A^{\prime}}{ }^{\prime} \perp-7^{\prime}\left(\perp H^{\prime}\right.$ & 400 & - & 23 & 0.20 & 12.2 & - & - & \\
\hline A71-771. & 400 & 6.9 & 50 & 0.76 & - & 88 & 77 & \\
\hline$A 72-012 A$ & 1000 & 7.6 & 56 & 0.83 & - & 268 & 89 & \\
\hline$A 72-004 E$ & 1650 & 2.1 & 9 & 0.23 & - & 349 & 10 & \\
\hline
\end{tabular}

Refer to Table I for footnotes

The same equations described previously were used to determine the values listed in Table 2 for this fibrous eutectic. The appreciable difference in shear stress and strain at the proportional limit for specimens tested under the sanle condilions bul with different strain measuring methods is also present in these results.

The torque vs angle of twist curves for the $(\mathrm{Co}, \mathrm{Cr}, \mathrm{Al})-(\mathrm{Cr}, \mathrm{Co}) \mathrm{C}_{3}$ alloy are shown in Fig. 8. Again, as in the previous eutectic alloy study, the torque at temperatures up to and including $1000^{\circ} \mathrm{F}$ increased with increasing angle of twist until it reached a maximum where the specimen failed. Only during the $1650^{\circ} \mathrm{F}$ test did the torque increase to a peak and then decrease before the specimen fractured. This peak occurred at an angle of twist of 320 degrees, a maximum shear stress of $15 \mathrm{x} 10^{3}$ psi and a shear strain of $35 \%$. Why the angle of twist at failure was less at $400^{\circ} \mathrm{F}$ than at room temperature is not presently understood. Also, the specimen tested at $1000^{\circ} \mathrm{F}$ experienced cracking, as noted in Fig. 8, well before final failure. The initial cracking was recorded at an angle of twist of 72.7 degrees. Using Fqs. (4) and (5), the shear stress and shear strain at crack initiation were calculated to be $70 \mathrm{x} 103$ psi and $7.9 \%$ respectively. The corresponding fractured specimens at room temperature (brittle fracture) and $1650^{\circ} \mathrm{F}$ (ductile failure) are also shown in Fig. 8.

\section{Fabricating Techniques}

\section{Grinding}

All the test specimens for determining the material properties pertinent to fastener application of both eutectic alloys were successfully fabricated by grinding. 
A typical flush head fastener shape of the $\mathrm{Ni}_{3} \mathrm{Al}^{-\mathrm{Ni}}{ }_{3} \mathrm{Cb}$ eutectic that was fabricated by grinding is shown in Fig. 9. The direction of solidification is parallel to the long axis of the fastener. Various lamellar orientations, all parallel to the growth direction, are evident from the two microstructural views in Fig. 9. Several double flush headed specimens were ground to shape from $\mathrm{Ni}_{3} \mathrm{Al-Ni}{ }_{3} \mathrm{Cb}$ ingots directionally solidified at $2 \mathrm{~cm} / \mathrm{hr}$ for use in evaluating this process as a method for fabricating fas leners.

Casting

Two mold designs were used for the purpose of determining the feasibility of directly casting the $\mathrm{Ni}_{3} \mathrm{Al}-\mathrm{Ni}{ }_{3} \mathrm{Cb}$ eutectic into a typical flush head fastener shape. One design allowed directional solidification to proceed from the fastener shank to the flush head and the other allowed directional solidification from the flush head shape into the shank. Figure 10 shows two eutectic ingots that were successfully sulidified at $2 \mathrm{~cm} / \mathrm{hr}$ using both of these designs. The center photographs in Fig. 10 show the ingots after removal from the high purity alumina mold in which they were directionally cast. There appears to be no indication of a metal-mold reaction. The outermost photographs show the cast fastener shapes after macro-etching their surfaces. It is evident from the grain alignment seen in these photographs that the solidification was directional.

A double flush headed specimen of the $\mathrm{Ni}_{3} \mathrm{Al}_{-} \mathrm{Ni}{ }_{3} \mathrm{Cb}$ eutectic that was cast into shape at $2 \mathrm{~cm} / \mathrm{hr}$ is shown in Fig. 11. The top photograph shows the ingot after removal from the high purity alumina mola in which it was directionally cast. Again, there appears to be no indication of a metal-mold reaction. Microstructural examination of the views shown in Fig. Il indicates a relatively gradual transition of the eutectic grain alignment through the two flush headed shapes of the cast ingot.

A few single and double $100^{\circ}$ flush headed specimens of the $\mathrm{Ni}_{3} \mathrm{Al}-\mathrm{Ni}{ }_{3} \mathrm{Cb}$ eutectic were directionally cast in order to evaluate this process as a method of fabricating fasteners.

\section{Crecp Forming}

Bar samples 0.250 inch diameter by approximately 2 inches long, of both the $\mathrm{Ni}_{3} \mathrm{Al}-\mathrm{Ni}{ }_{3} \mathrm{Cb}$ and the $(\mathrm{Co}, \mathrm{Cr}, \mathrm{Al})-(\mathrm{Cr}, \mathrm{Co}){ }_{7} \mathrm{C}_{3}$ eutectics were ground with the direction of solidification parallel to the long dimension. Several attempts were made to hot forge the ends of these samples with a $100^{\circ}$ flush head die. The two major problems encountered were the lack of temperature control and the high strain rate which in some cases caused the material to shatter. A hot forging temperature of approximately $2200^{\circ} \mathrm{F}$ was selected but often the sample temperature fell well below this level and in other instances some melting of the sample was evident.

These initial experiments led to the belief that a creep forming process where temperature and strain rate can be better controlled, may prove worthwhile in producing a satisfactory flush head fastener shape. Bar samples, 0.250 inch diameter by approximately 1.7 inches long, of both eutectics were ground with the direction of solidification parallel to the long dimension. Both alloys were successfully creep formed into a flush head fastener shape (Figs. 12, 13 and 14) using a molybdenum die. The forming was accomplished in vacuum at $2200^{\circ} \mathrm{F}$ at a rate of approximately 0.015 inch per minute and a pressure of approximately $25 \times 10^{3}$ psi. The $100^{\circ}$ flush head formed was 0.40 inch in diameter and 0.06 inch high. No distortion occurred, the materials completely filled the die, and there was no problem with die release as the difference in thermal expansion between the die material and the alloys being formed automatically provides adequate clearance on cooling. Metallographic examination indicated favorable phase distribution and flow in the flush head area of both alloys (Figs. 13 and 14). 
Several specimens were fabricated to determine the shear strength of these eutectic materials when made into a typical f'astener shape using the creep t'orming process.

\section{Evaluation of Fabricated Fasteners}

The material properties pertinent to fastener applications which have been determined for both the lamellar $\mathrm{Ni}_{3} \mathrm{Al}-\mathrm{Ni}{ }_{3} \mathrm{Cb}$ and the fibrous (Co, $\left.\mathrm{Cr}, \mathrm{Al}\right)-(\mathrm{Cr}, \mathrm{Co}) \mathrm{C}_{3}$ directionally solidified eutectic alloys are encouraging and indicate that these alloys show promise as candidate materials for high temperature fastener applications.

A $100^{\circ}$ countersunk flush head design was chosen as a typical fastener shape for the evaluation of fabricated fasteners because this configuration is common in the assembly of skin panels to substructures where a flush surface is requirea.

Room Temperature Shear Strength

The longitudinal thread shear results for both eutectics indicated that shearing of lhreads was not a major problem. This study revealed that wilh adequale lhread engagement (more than two threads) failure would occur either by shear or tension at the fastener head or by tension through the root of the thread. With this knowledge and because of the directional nature of these eutectic microstructures which are affected by the processing method, the shear strength evaluation of fabricated fasteners was centered around the determination of the effective shear strength of the fastener heads only.

The results of the room temperature shear strength evaluation of $100^{\circ}$ flush head fastener shapes of the $\mathrm{Ni}_{3} \mathrm{Al}_{-} \mathrm{Ni}_{3} \mathrm{Cb}$ eutectic for the three fabrication techniqucs arc listed in Table 3. The double headed specimen configurations were tested in the same manner as described in the longitudinal shear strength determinations. The single headed fastener configurations were tested using a V-type wedge grip with serrated faces which clamped around the shank of the fastener.

Table 3

Room Temperature Shear Strength Evaluation of $100^{\circ}$ Flush Head Fastener Shape of $\mathrm{Ni}_{3} \mathrm{Al}_{-} \mathrm{Ni}_{3} \mathrm{Cb}$ Eutectic Soliaified at $2 \mathrm{~cm} / \mathrm{hr}$

\begin{tabular}{|c|c|c|c|c|}
\hline $\begin{array}{l}\text { Specimen } \\
\text { Number } \\
\end{array}$ & $\begin{array}{c}\text { Fabrication } \\
\text { Technique }\end{array}$ & $\begin{array}{c}\text { Specimen } \\
\text { Configuration } \\
\end{array}$ & $\begin{array}{l}\text { Effective } \\
\text { Shear Stress } \\
\text { psi }\end{array}$ & Failure Mode \\
\hline$A 71-735 A$ & ground & double headed & 37,200 & Shear \& Tensile \\
\hline $\mathrm{ATI}-735 \mathrm{~B}$ & grouna & double hledaed & 26,400 & Whear \& Tensile \\
\hline A72-217 & cast & double headed & 24,000 & Tensile \\
\hline$A 72-237$ & cast & double headed & 23,400 & Shear \& Tensile \\
\hline$A 72-217 \mathrm{a}$ & cast & single headed & 20,000 & Shear \& Tensile \\
\hline A71-692 & cast & single headed & 31,200 & Shear \& Tensile \\
\hline$A 71-694$ & cast & single headed & 26,300 & Shear \& Tensile \\
\hline$A 71-461-02$ & creep formed & single headed & 14,900 & $\begin{array}{l}\text { Tensile (cellular } \\
\text { microstructure) }\end{array}$ \\
\hline$A 71-493-1$ & creep formed & single headed & 31,600 & $\begin{array}{l}\text { Tensile (lamellar } \\
\text { microstructure) }\end{array}$ \\
\hline
\end{tabular}


Most of the effective shear stress values listed in Table 3 compare favorably with those plotted in Fig. 4 with the following exceptions, the higher value of 37,200 psi. for the double headed ground specimen and the lower value of 14,900 psi for the creep formed specimen. This low value can be explained by the fact that microstructural examination after testing revealed that the specimen contained a cellular microstructure near the fastener head. This local breakdown in the lamellar microstructure could cause a weakening of the material in that area when exposed to $2200^{\circ} \mathrm{F}$ during the forming process.

A limited evaluation of the (Co,Cr, Al)-(Cr, Co) ${ }_{7} \mathrm{C}_{3}$ eutectic is given in Table 4. These specimens were all creep formed and the first two tested yielded values that compare closely to the values plotted in Fig. 5 which were determined using ground specimens. The third test of a creep formed specimen resulted in a much higher effective shear stress than the previous two. These results are quite encouraging and indicate that a more concentrated study into the feasibility of a thermal mechanical working process as a fabricating technique for eutectic materials should be continued.

Table 4

Room Temperature Shear Strength Evaluation of $100^{\circ}$ Flush Head Fastener Shape of (Co, $\mathrm{Cr}, \mathrm{Al})-(\mathrm{Cr}, \mathrm{CO}) 7_{3} \mathrm{C}_{3}$ Eutectic Solidified at $10 \mathrm{~cm} / \mathrm{hr}$

\begin{tabular}{|c|c|c|c|c|}
\hline $\begin{array}{l}\text { Specimen } \\
\text { Number } \\
\end{array}$ & $\begin{array}{l}\text { Fabrication } \\
\text { Technique }\end{array}$ & $\begin{array}{c}\text { Specimen } \\
\text { Configuration } \\
\end{array}$ & $\begin{array}{c}\text { Effective } \\
\text { Shear Stress } \\
\text { psi }\end{array}$ & Failure Mode \\
\hline $\begin{array}{l}\# 1 \\
\# 2 \\
\# 3\end{array}$ & $\begin{array}{l}\text { creep formed } \\
\text { creep formed } \\
\text { creep formed }\end{array}$ & $\begin{array}{l}\text { single headed } \\
\text { single headed } \\
\text { single headed }\end{array}$ & $\begin{array}{l}42,600 \\
45,700 \\
68,800\end{array}$ & $\begin{array}{l}\text { Tensile } \\
\text { Tensile } \\
\text { Tensile }\end{array}$ \\
\hline
\end{tabular}

Etiect of Flush Head Angle on Room Temperature Shear Strength

Double flush hcaded specimens of the $\mathrm{Ni}_{3} \mathrm{Al}_{-} \mathrm{Ni} \mathrm{H}_{3} \mathrm{Cb}$ eutectic which were ground to shape, were tested to determine the effective longitudinal shear strength (shear paraliel to the direction of solidification) at room temperature of this material. as a function of flush head angle. The effect of flush head angle on the room temperature longitudinal shear strength of this alloy is shown in Fig. 15. The influence of higher compressive forces perpendicular to the tapered surface are evident by the increase in the effective shear strength with a decrease in flush head angle.

Al1 rom temperature shear strength evaluation tests were performed at a loading rate of $0.01 \mathrm{in./min}$ and the fastener shank diameter ( $0.250 \mathrm{inch}$ ) and height of fractured head were used in calculating the shear area.

Effect on Room Temperature Torsional Strength after Exposure at 2200 $\mathrm{F}$

Directionally solidified ingots of both the $\mathrm{Ni} 3_{3} \mathrm{Al}-\mathrm{Ni}{ }_{3} \mathrm{Cb}$ and $(\mathrm{Co}, \mathrm{Cr}, \mathrm{AI})-(\mathrm{Cr}, \mathrm{Co}){ }_{7} \mathrm{C}_{3}$ eutectics were prepared and ground into torsion specimens for room tempcrature torsional tests after exposure at $2200^{\circ} \mathrm{F}$ for 30,60 , and 120 minutes. These results are shown in Tables 5 and 6 . Little or no effect can be seen on the room temperature torsional strength after exposure at $2200^{\circ} \mathrm{F}$ in the $\mathrm{Ni}_{3} \mathrm{Al}-\mathrm{Ni}{ }_{3} \mathrm{Cb}$ eutectic whereas a slight effect is evident in the (Co, $\mathrm{Cr}, \mathrm{Al})-(\mathrm{Cr}, \mathrm{Co})_{7} \mathrm{C}_{3}{ }^{3}$ alloy. 
Table 5

Effect on the Room Temperature Torsional Strength of $\mathrm{Ni}_{3} \mathrm{Al}-\mathrm{Ni}{ }_{3} \mathrm{Cb}$ Eutectic Solidified at $2 \mathrm{~cm} / \mathrm{hr}$ after Exposure at $2200^{\circ} \mathrm{F}$

\begin{tabular}{|c|c|c|c|c|c|c|c|}
\hline $\begin{array}{l}\text { Specimen } \\
\text { Number }\end{array}$ & $\begin{array}{l}\text { Exposure } \\
\text { rime } \\
\text { min }\end{array}$ & $\begin{array}{l}\theta_{\mathrm{PL}} \\
\mathrm{deg} .\end{array}$ & $10^{3^{\mathrm{PL}}} \mathrm{pSi}$ & ${ }_{\substack{P L \\
\%}}$ & $\begin{array}{r}{ }_{f} \\
\mathrm{deg} .\end{array}$ & $10^{3^{f}} \mathrm{psi}$ & $\gamma_{\frac{f}{q}}$ \\
\hline 伍 & 0 & 6.9 & 42 & 0.76 & 113 & 72 & 12 \\
\hline $72-180$ & 30 & 6.6 & 44 & 0.72 & 121 & 70 & 13 \\
\hline A72-336 & 60 & 6.6 & 39 & 0.72 & 131 & 78 & 14 \\
\hline A72-196 & 120 & 6.9 & 47 & 0.76 & 120 & 72 & 13 \\
\hline
\end{tabular}

strain measured by a time scale which was converted to an angle of twist measurement gage length $=1$ inch

rate of applied torque $=.67 \mathrm{RPM}$

$\tau_{P L}, \tau_{f} \equiv$ shear stresses at proportional limit and at failure

$\gamma_{p I}, \gamma_{f}^{2}=$ shear strains at proportional limit and at failure

$\theta_{\mathrm{PL}}, \theta_{\mathrm{f}} \equiv$ angle of twist at proportional limit and at failure

Table 6

Effect on the Room Temperature Torsional Strength of (Co, Cr, Al)-(Cr, Co $)_{7} \mathrm{C}_{3}$ Eutectic Solidified al $10 \mathrm{~cm} / \mathrm{hr}$ after Txposure at $2200^{\circ} \mathrm{F}$

\begin{tabular}{|c|c|c|c|c|c|c|c|}
\hline $\begin{array}{l}\text { Specimen } \\
\text { Number }\end{array}$ & $\begin{array}{l}\text { Exposure } \\
\text { Time } \\
\text { min } \\
\end{array}$ & $\begin{array}{l}{ }^{\theta} \mathrm{PI} \\
\text { deg. }\end{array}$ & $103^{\tau_{\mathrm{PL}}} \mathrm{psi}$ & $\begin{array}{l}\gamma_{\mathrm{PL}} \\
\underline{p_{0}} \\
\end{array}$ & $\begin{array}{r}\theta_{f} \\
\text { deg. }\end{array}$ & $10^{\tau} f^{f}$ psi & $Y_{t}$ \\
\hline$A 71-771 B$ & 0 & 6.9 & 56 & 0.76 & 126 & 89 & \\
\hline A72-009D & 30 & 5.2 & 39 & 0.57 & 166 & 92 & \\
\hline A72-009E & 60 & 5.9 & 36 & 0.64 & 175 & 84 & 19 \\
\hline A72-004F & 120 & 6.8 & 45 & 0.74 & 225 & 96 & \\
\hline
\end{tabular}

Refer to Table 5 for footnotes

Shear-Rupture

Directionally solidified ingots of the $\mathrm{Ni}_{3} \mathrm{Al}_{-} \mathrm{Ni}_{3} \mathrm{Cb}$ eutectic alloy were preparcd and ground into double headed longitudinal shear specimens for short-term stressrupture tcsting. The specimen design used was the same as described in the longitudinal shear strength determinations. The resulting data are plotted in Fig. 16 and are compared with longitudinal-rupture data obtained for this eutectic from a previous study (I) and with thread-rupture data for ID NiCr (10).

\section{Conclusions}

The present program has revealed that both the lamellar $\mathrm{Ni}_{3} \mathrm{Al}_{\mathrm{I}} \mathrm{Ni}_{3} \mathrm{Cb}$ and the fibrous ( $\mathrm{Co}, \mathrm{Cr}, \mathrm{Al})-(\mathrm{Cr}, \mathrm{Co}){ }_{7} \mathrm{C}_{3}$ directionally solidified eutectic alloys show promise as candidate materials for high temperature fastener applications. Although no torsion data were available for comparison, the transverse shear values obtained for volh eutectic alloys (based on double shear testing) indicated equal or higher 
strengths than that reported for dispersion strengthened metals (e.g. TD NiCr) which were selected in a previous study for potential use as structural fasteners. The stress-rupture characteristics of the $\mathrm{Ni}_{3} \mathrm{Al}_{-}-\mathrm{Ni} 3 \mathrm{Cb}$ eutectic compare favorably with that of TD NiCr considering the difference in the testing mode used in obtaining the data. Finally, this study has indicated that a eutectic material can be successfully formed to shape by grinding, casting, and thermal-mechanical working (creep forming).

\section{Acknowledgements}

The author gratefully acknowledges Dr. E. R. Thompson and Dr. C. O. Hulse for their technical contributions to the accomplishment of the program goals, Mr. J. Hermann for his metallographic work, and Miss J. Hurlburt and Mrs. D. Gelinas for preparing the manuscript.

\section{References}

1. Thompson, E. R. and F. D. George: Investigation of the Structure and Properties of the $\mathrm{Ni}_{3} \mathrm{Al}-\mathrm{Ni}{ }_{3} \mathrm{Cb}$ Eutectic Alloy. Final Report, Contract N00019-69-C-0162 (July 31,1969$)^{3}$.

2. Thumpson, E. R. and F. D. Lemkey: Structure and Properties of Ni 3 Al $\left(\gamma^{\prime}\right)-B a s e d$ Eutectic Alloys. ASM Trans. Quarterly, Vol. 62, pp 140-154 (1969).

3. Thompson, E. R. and F. D. George: Eutectic Superalloys. 1969 SAE Transactions, Vol. $78, \mathrm{p} 2283$ (Dec. 1970).

4. Thompson, E. R., F. D. George, and E. H. Kraft: Investigation to Develop a High Strength Eutectic Alloy with Controlled Microstructure. Final Report, Contract N00019-70C-0052 (July 31, 1970).

5. Thompson, E. R., E. H. Kraft, and F. D. George: Investigation to Develop a High Strength Eutectic for Aircraft Engine Use. Final Report, Contract No0019-71-C0096 (July 31, 1971).

6. Thompson, E. R. and F. D. Lemkey: Unidirectional Solidification of CobaltChromium-Carbon Monovariant Eutectic Alloys. Met. Trans. Vol. 1, p 2799 (1970).

7. Thompson, I. R., D. A. Koss, and J. C. Chesnutt: Mechanical Behavior of a Carbide Reinforced Cobalt-Chromium Eutectic Alloy. Mct. Trans., Vol. 1, p 2807 (1970).

8. Lemkey, F. D. and E. R. Thompson: Nickel and Cobalt Eutectic Alloys Reinforced by Refractory Metal Carbides. Met. Trans.., Vol. 2, p 1537 (1971).

9. Thompson, E. R.: Anisotropic Toughness of a Carbide Reinforced Cobalt, Chromium Eutectic. J. Composite Mat., Vol. 5, p 235 (1971).

10. Roach, T. A.: Dispersion Strengthened Metals Structural Mechanical Fastener Evaluation. Tech. Report AFFDL-TR-68-89 (June 1968).

11. Thornton, P. H., R. G. Davies, and T. L. Johnston: The Temperature Dependence of the Flow Stress of the $y^{\prime}$ Phase Based Upon Ni3Al. Met. Trans., Vol. 1, $p 207$ (1970). 

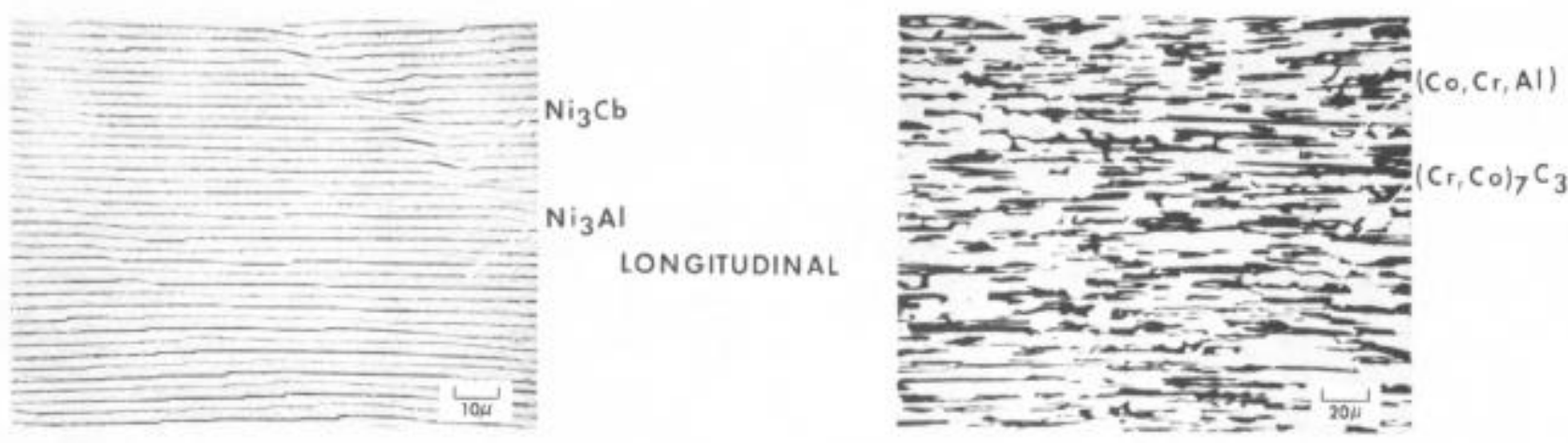

$\stackrel{\complement}{\dot{\omega}}$

LONGITUDINAL

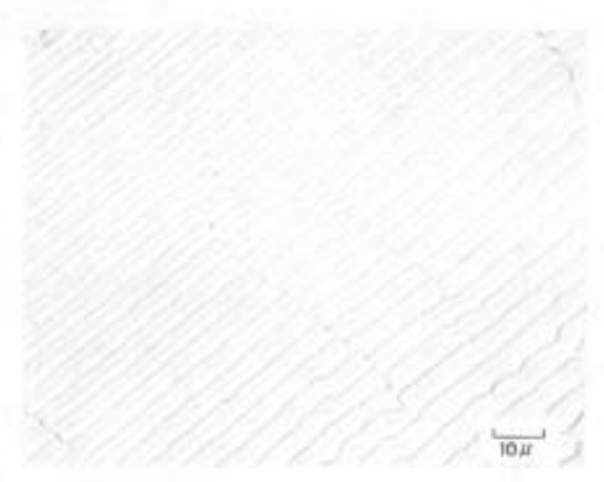

TRANSVERSE

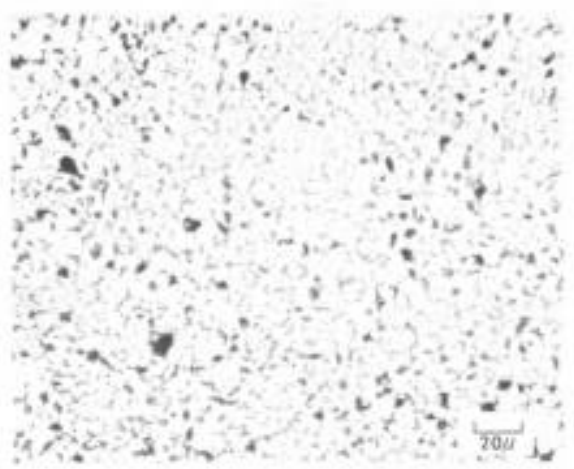

Figure 1. Microstructure of Unidirectionally Solidified $\mathrm{Ni}_{3} \mathrm{Al}-\mathrm{Ni}_{3} \mathrm{Cb}$ and $(\mathrm{Co}, \mathrm{Cr}, \mathrm{Al}) \cdot(\mathrm{Cr}, \mathrm{Co})_{7} \mathrm{C}_{3}$ Eutectics 


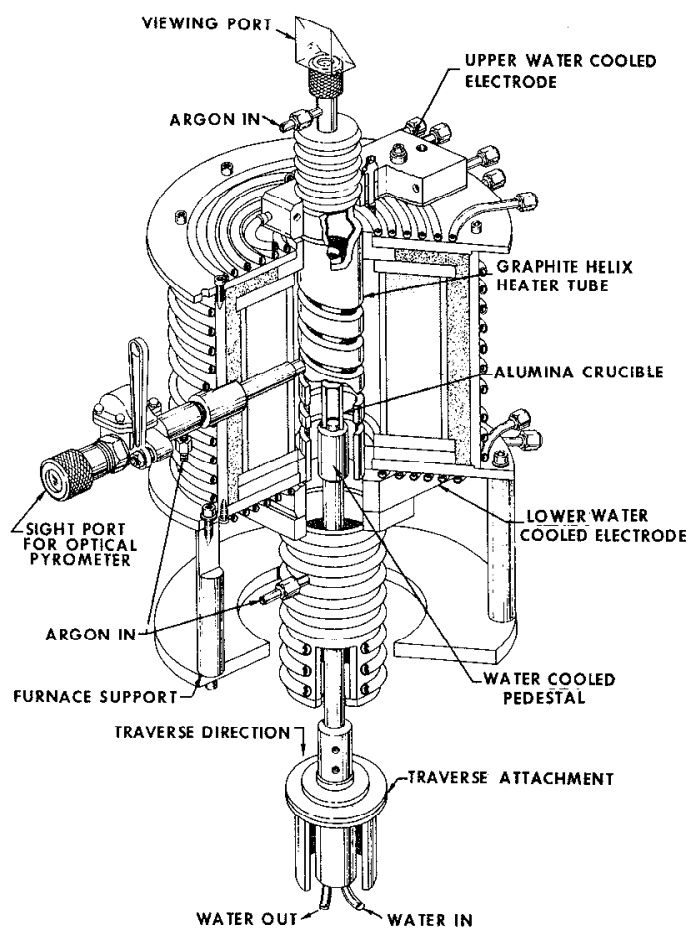

Figure 2. Graphite Directional Solidification Furnace 

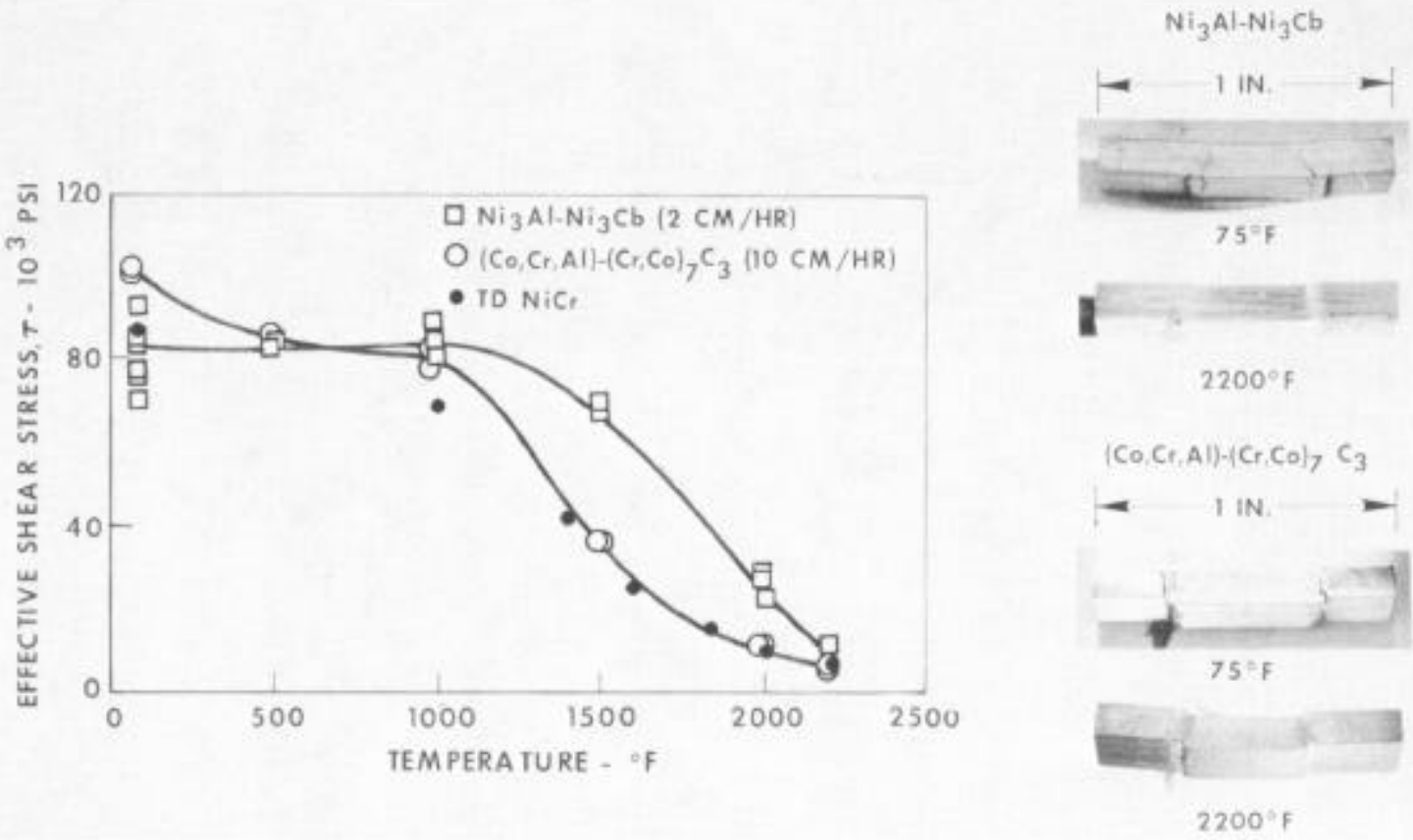

Figure 3. Temperature Dependence of Transverse Shear Strength
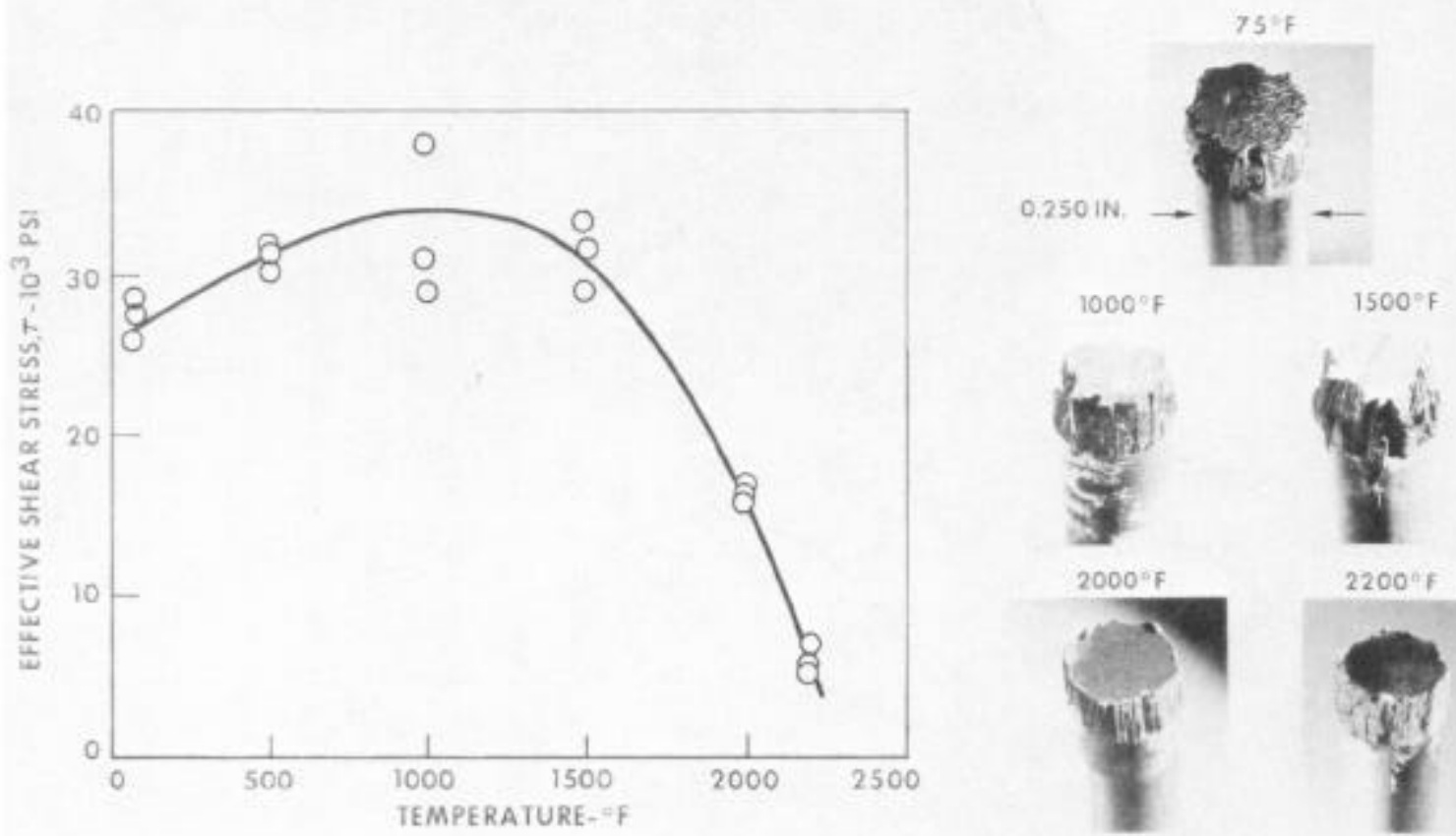

Figure 4. Temperature Dependence of Longitudinal Shear Strength of $\mathrm{Ni}_{3} \mathrm{Al}^{-\mathrm{Ni}_{3}} \mathrm{Cb}$ Eutectic Solidified at $2 \mathrm{~cm} / \mathrm{hr}$ 


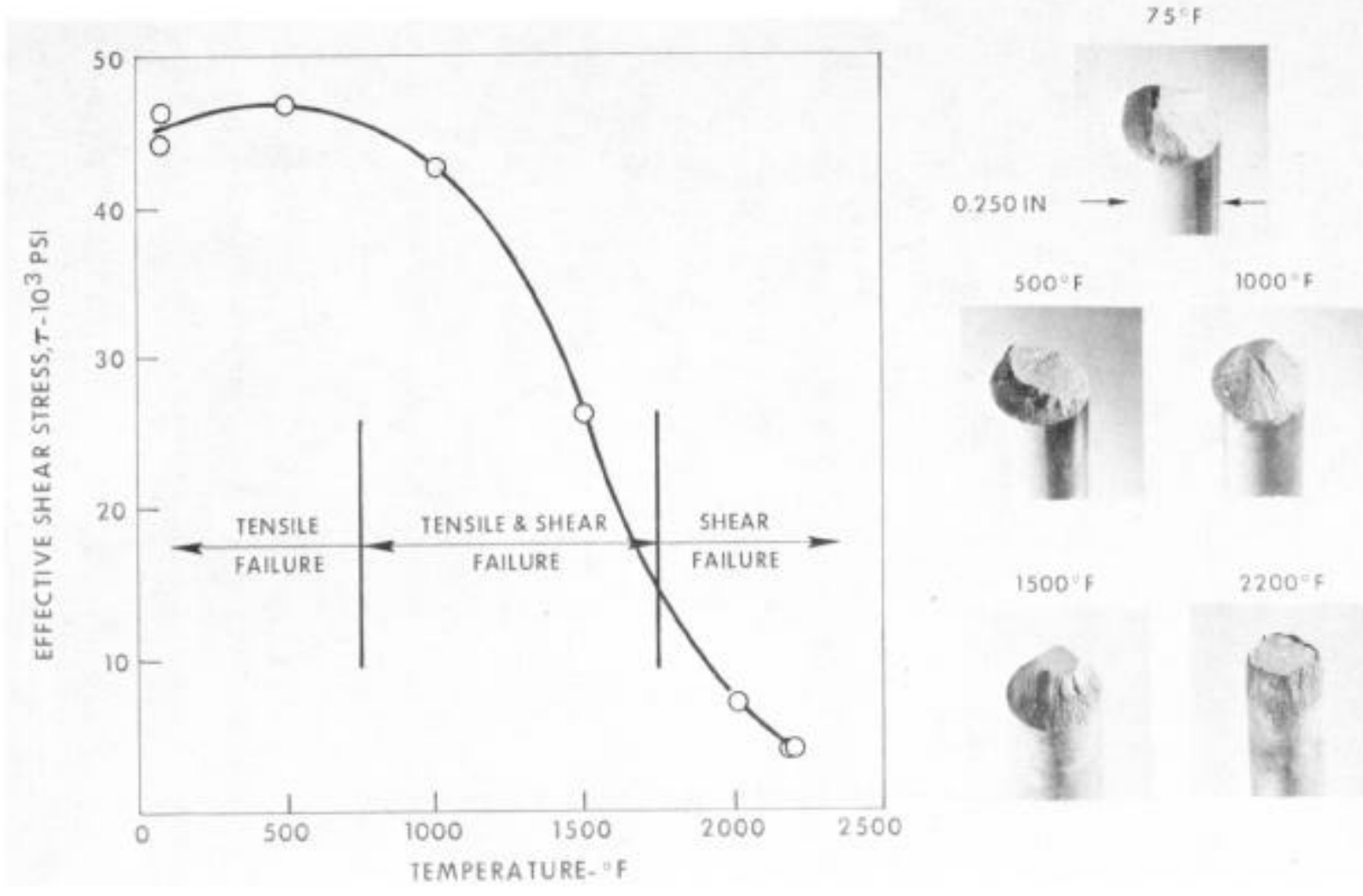

Figure 5. Temperature Dependence of Longitudinal Shear Strength of $(\mathrm{Co}, \mathrm{Cr}, \mathrm{Al}) \cdot(\mathrm{Cr}, \mathrm{Co})_{7} \mathrm{C}_{3}$ Eutectic Solidified at $10 \mathrm{~cm} / \mathrm{hr}$

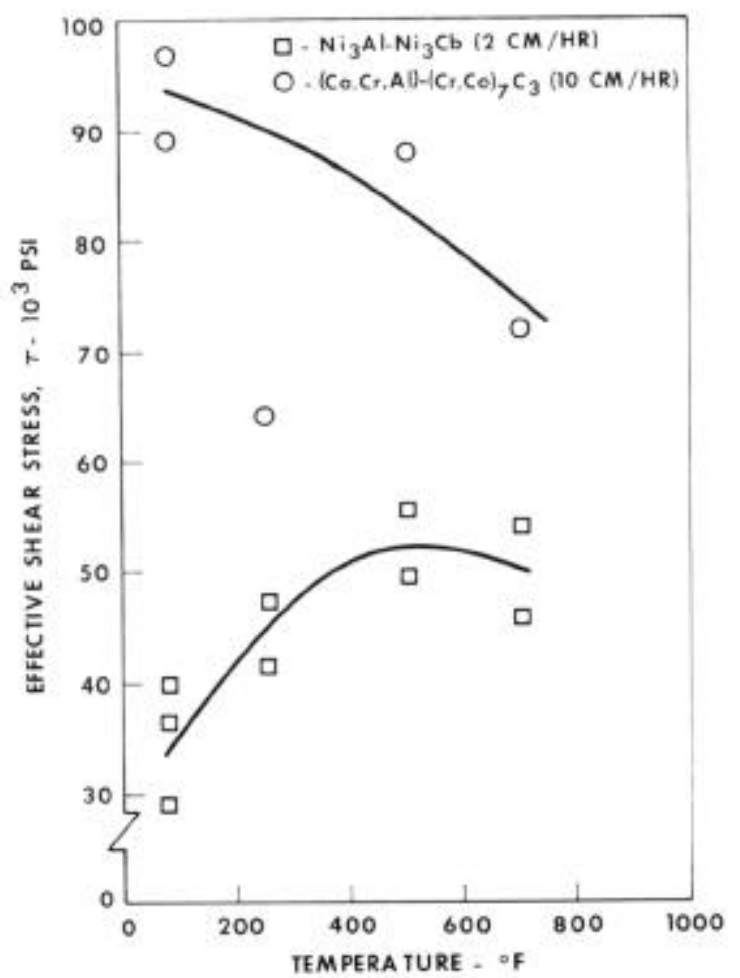

Figure 6. Temperature Dependence of Longitudinal Thread Shear Strength 


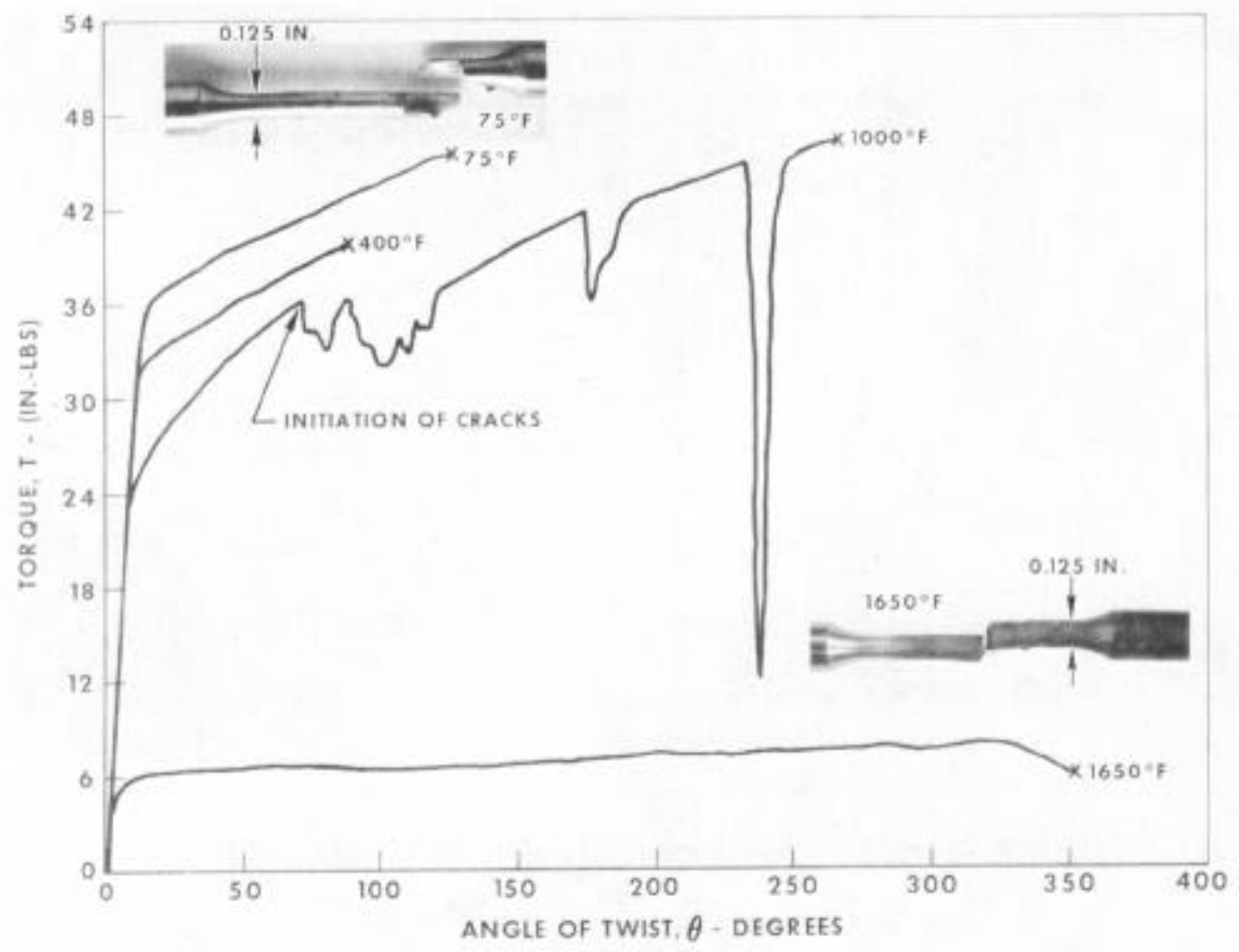

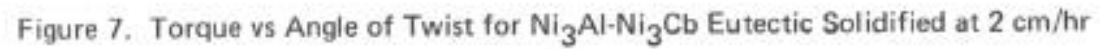

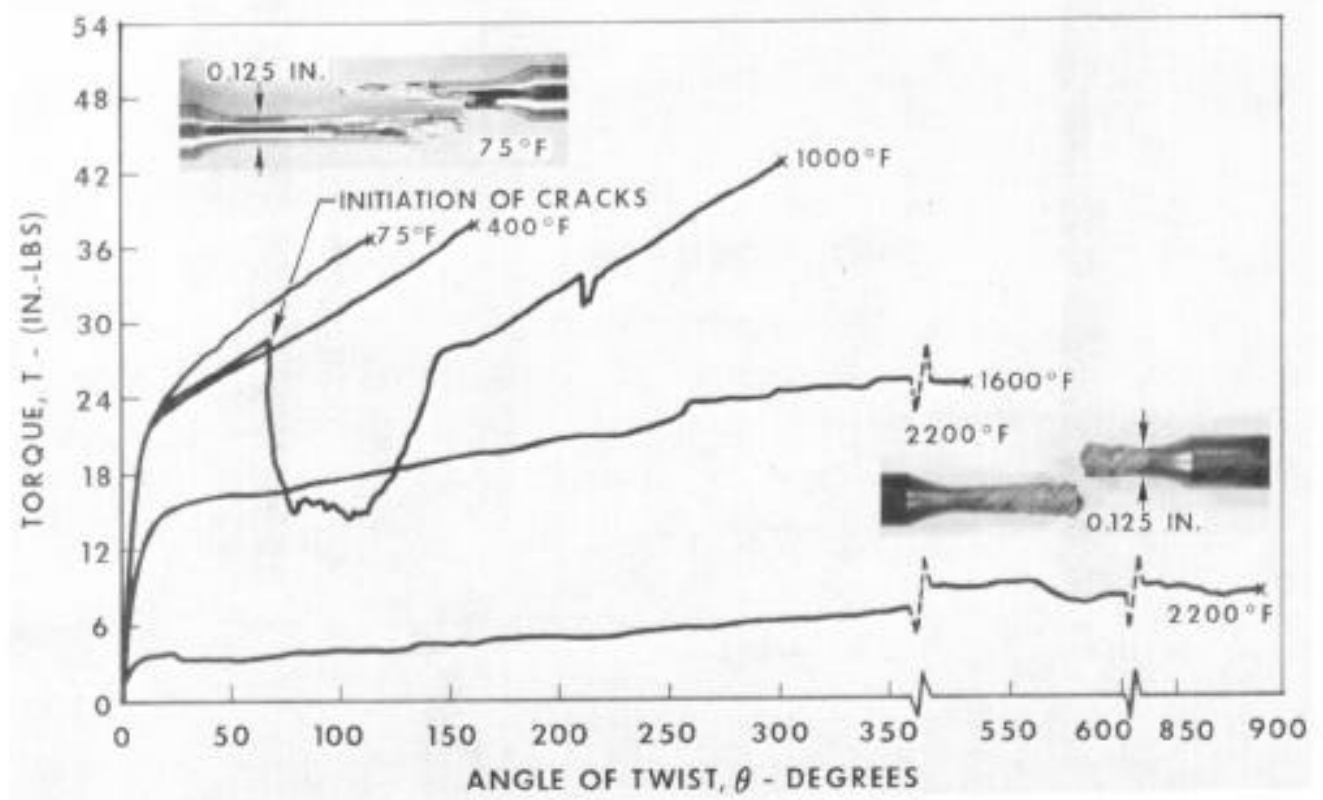

Figure 8. Torque vs Angle of Twist for $(\mathrm{Co}, \mathrm{Cr}, \mathrm{Al})-(\mathrm{Cr}, \mathrm{Co})_{7} \mathrm{C}_{3}$ Eutectic Solidified at $10 \mathrm{~cm} / \mathrm{hr}$ 


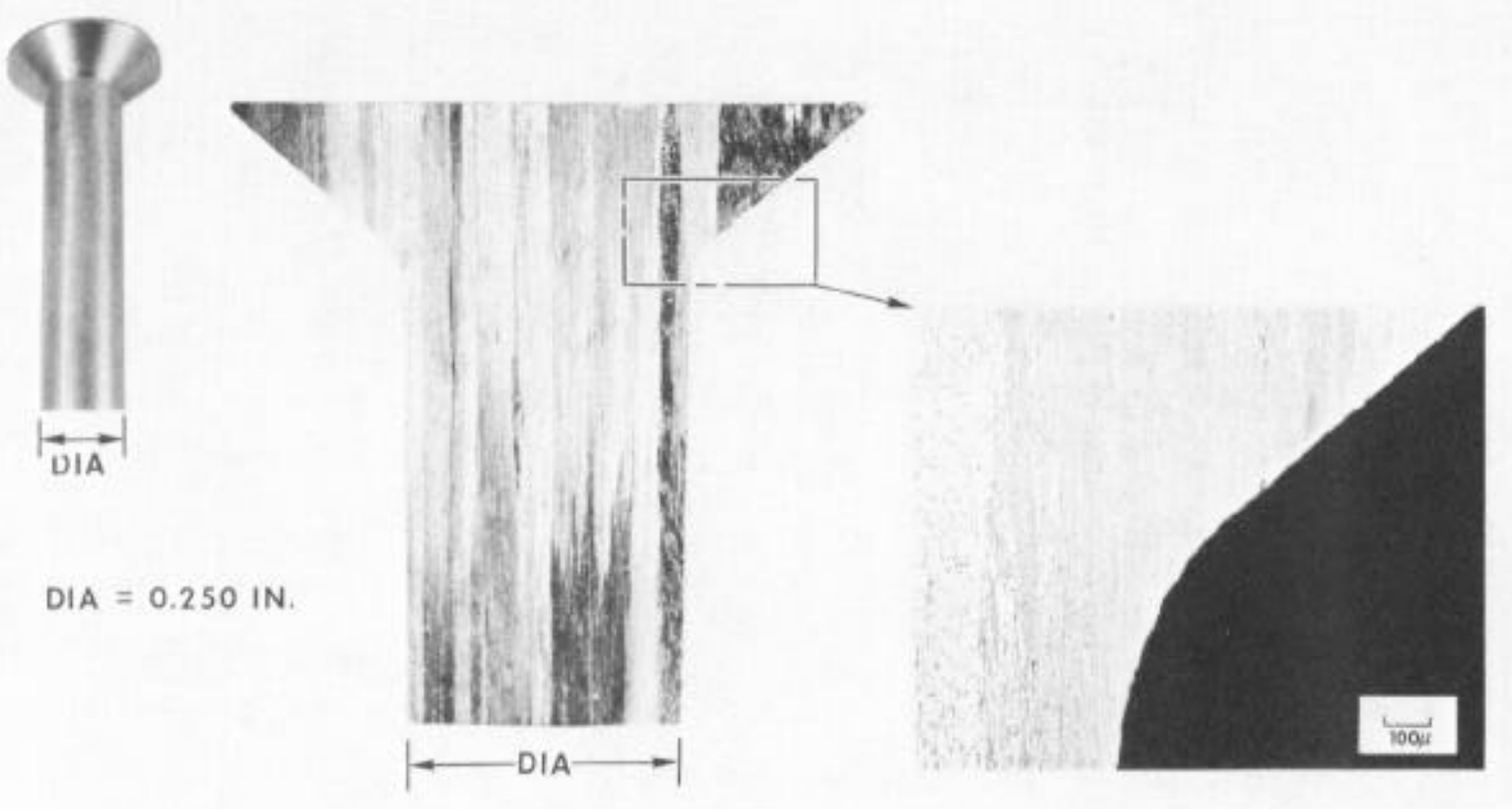

Figure 9. Ground Flush Head Fastener Shape of the $\mathrm{Ni}_{3} \mathrm{Al}^{-\mathrm{Ni}_{3}} \mathrm{Cb}$ Eutectic

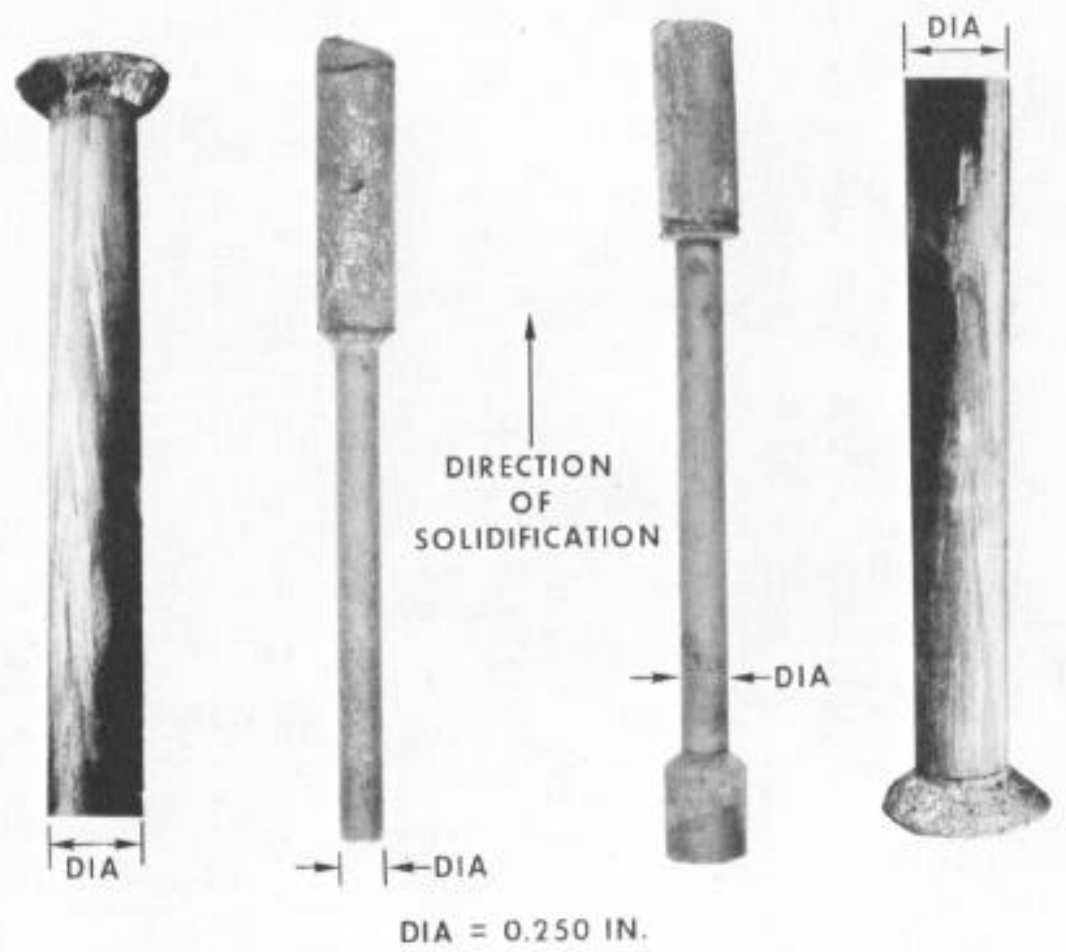

Figure 10. Cast Single Flush Head Fastener Shapes of the $\mathrm{Ni}_{3} \mathrm{Al}-\mathrm{Ni}_{3} \mathrm{Cb}$ Eutectic 


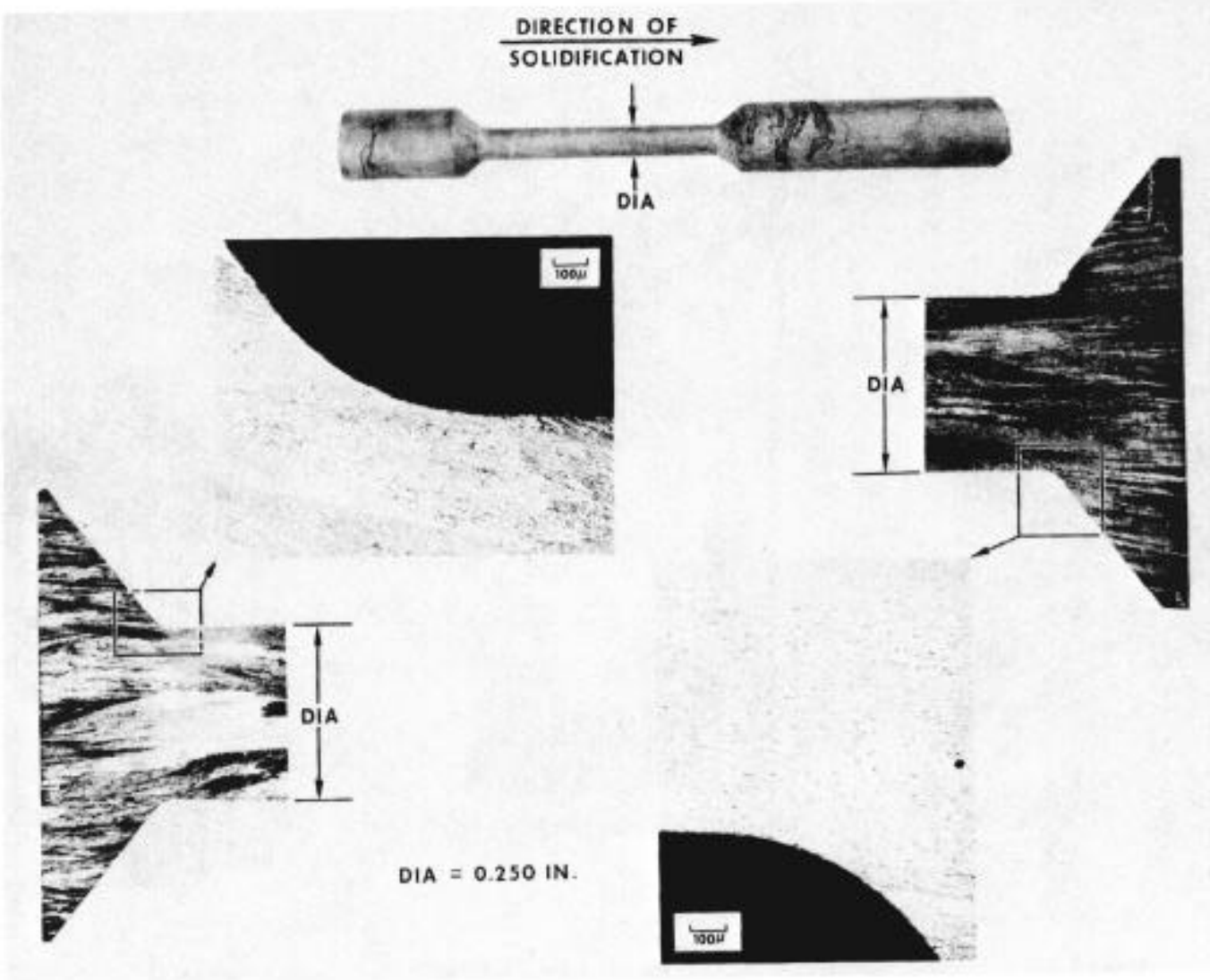

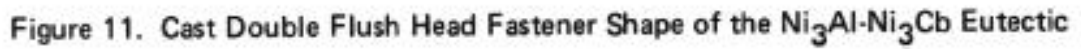

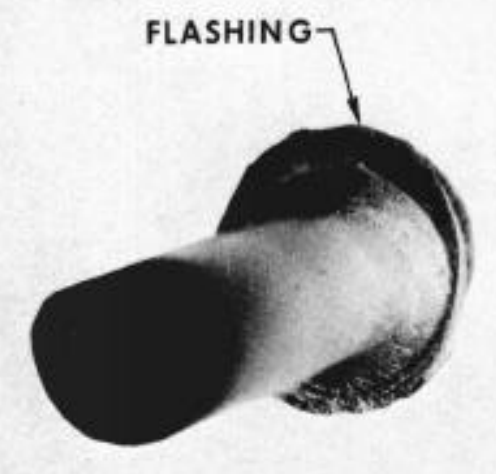

AS FORMED - WITH FLASHING AROUND FASTENER HEAD

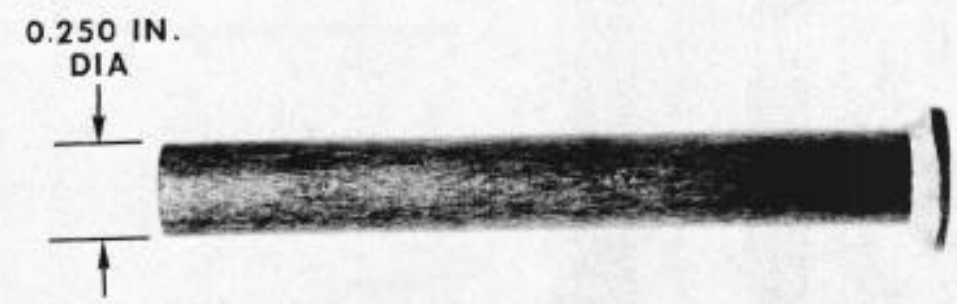

\section{AFTER GRINDING HEAD AND MACRO-ETCHING FASTENER SURFACE}

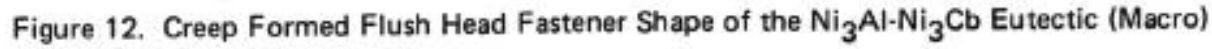




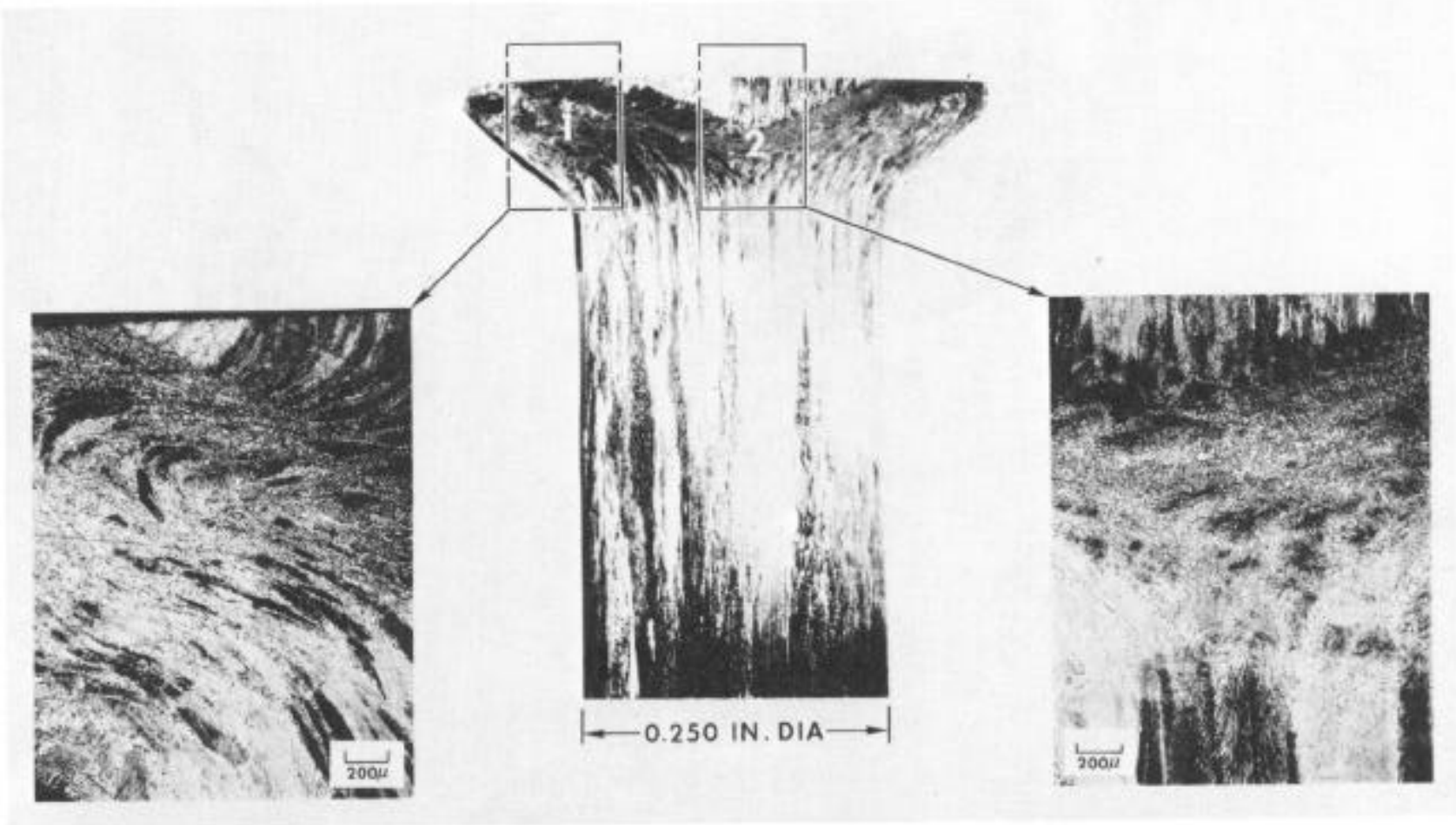

Figure 13. Creep Formed Flush Head Fastener Shape of the $\mathrm{Ni}_{3} \mathrm{Al} \cdot \mathrm{Ni}_{3} \mathrm{Cb}$ Eutectic (Micro)
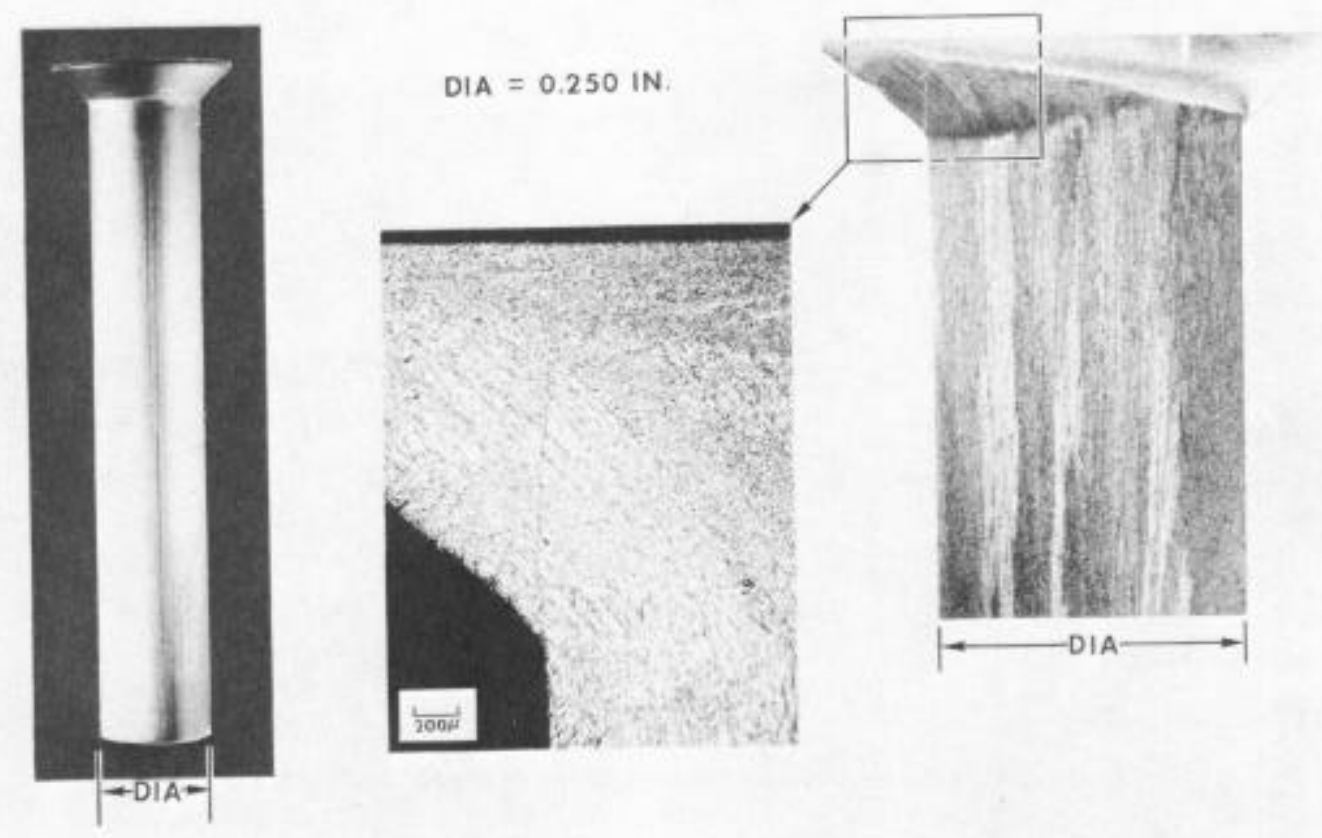

Figure 14. Creep Formed Flush Head Fastener Shape of the $(\mathrm{Co}, \mathrm{Cr}, \mathrm{Al})-(\mathrm{Cr}, \mathrm{Co}){ }_{7} \mathrm{C}_{3}$ Eutectic 


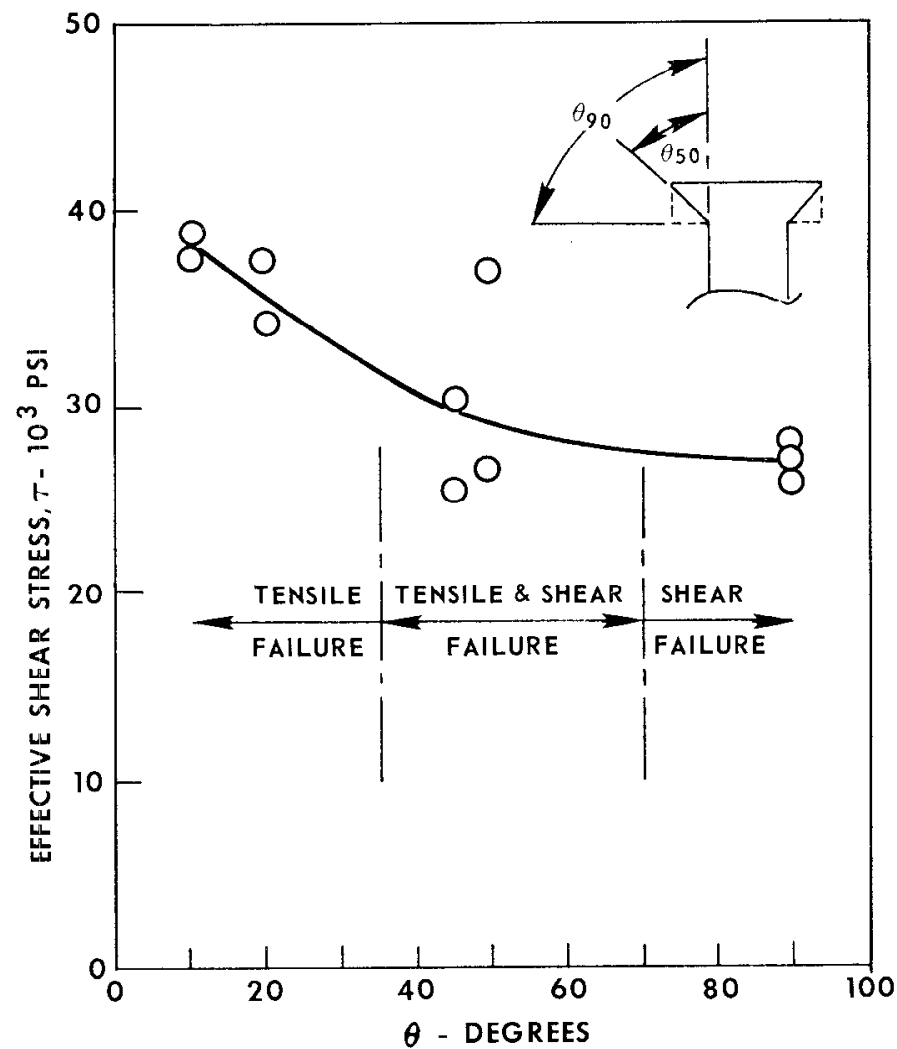

Figure 15. Room Temperature Shear Strength Evaluation of Ground Fastener Shapes of

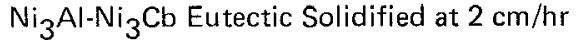

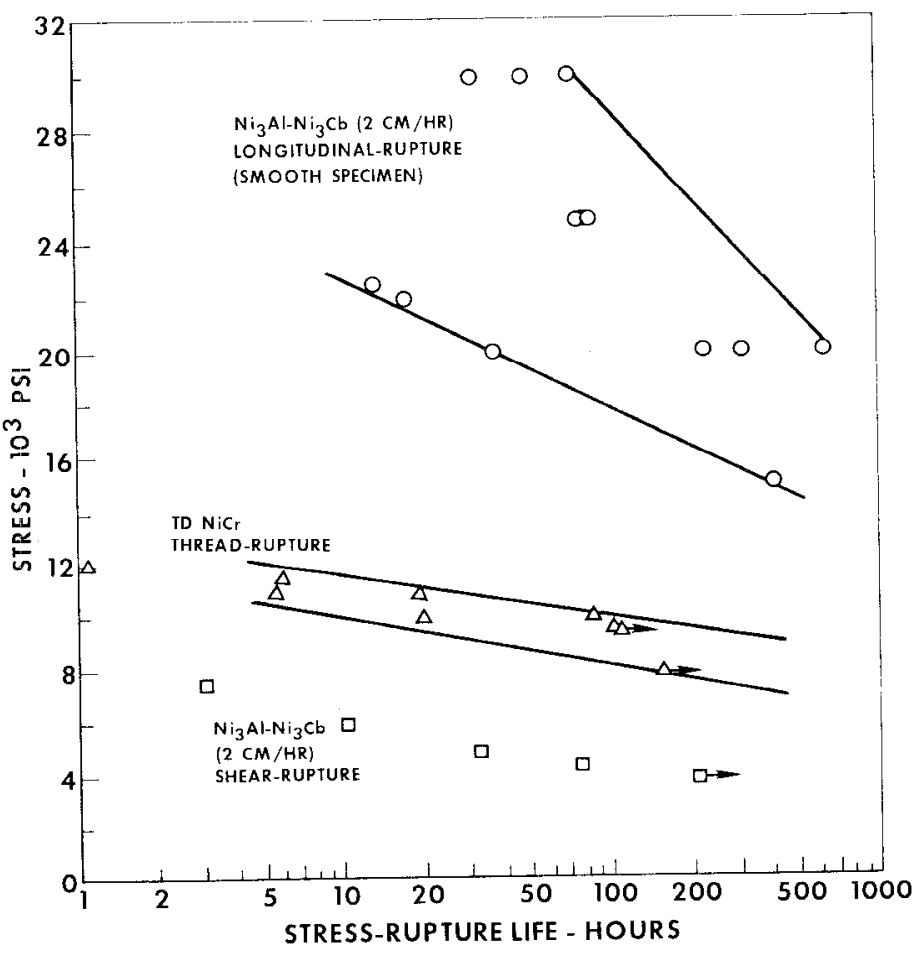

Figure 16. Stress-Rupture Life vs Stress at $2000 \mathrm{~F}$ 